American University Washington College of Law

Digital Commons @ American University Washington College of

Law

Articles in Law Reviews \& Other Academic Journals

Scholarship \& Research

1993

Confirming the Constitution: The Role of the Senate Judiciary

Committee

Stephen Wermiel

Follow this and additional works at: https://digitalcommons.wcl.american.edu/facsch_lawrev

Part of the Constitutional Law Commons, Judges Commons, and the Legal History Commons 


\title{
CONFIRMING THE CONSTITUTION: THE ROLE OF THE SENATE JUDICIARY COMMITTEE
}

\author{
STEPHEN J. WERMIEL*
}

\section{INTRODUCTION}

When the Supreme Court reached its usual frenetic climax for the October Term 1991, the decisions in Planned Parenthood v. Casey ${ }^{1}$ and Lee v. Weisman ${ }^{2}$ surprised many observers and Court pundits. Instead of overturning Roe $v$. Wade, ${ }^{3}$ the Court reaffirmed a woman's right to choose to terminate a pregnancy in the Casey decision, and instead of cutting back on the principle of church-state separation, the Court reaffirmed it in the Weisman decision, at least as it applies to official benedictions at public school graduation ceremonies.

Besides the outcomes, the biggest surprises in these two important decisions were the positions of two members of the Court: Justices Anthony M. Kennedy and David H. Souter. Appointed by President Ronald Reagan and President George Bush respectively, the two Justices had been widely expected to reflect the moral values of the presidents who put them on the Court. They were expected to produce constitutional decisions overturning Roe in the Casey decision and allowing greater accommodation of religion in public life in Weisman.

There is one place, however, in which the role of these two Justices in the Casey and Weisman decisions was less surprising: the Judiciary Committee of the U.S. Senate. In the post-Bork ${ }^{4}$ era of Supreme Court nominations, members of the Judiciary Committee have learned to shape the constitutional dialogue in confirmation hearings to make clear to nominees that a willingness to profess

Copyright $\mathfrak{1} 1993$ by Law and Contemporary Problems

* Associate Professor, Georgia State University College of Law.

As the Supreme Court correspondent for the Wall Street Journal from 1979 to 1991, the author covered the confirmation hearings of Justices Sandra Day O'Connor, Antonin Scalia, Anthony Kennedy, and David Souter, Chief Justice William Rehnquist, and Judge Robert Bork. Earlier, as a Washington correspondent for the Boston Globe, he covered the confirmation of Justice John Paul Stevens.

The author wishes to thank Professor Neal Devins of the Marshall-Wythe School of Law at the College of William and Mary for his patience and encouragement and Pamela Corley of the Georgia State University College of Law for her research assistance.

1. 112 S. Ct. 2791 (1992).

2. 112 S. Ct. 2649 (1992).

3. 410 U.S. 113 (1973).

4. The Senate rejected President Ronald Reagan's nomination of Judge Robert H. Bork to the Supreme Court on October 23, 1987, by a vote of 58-42. 113 CONG. REC. S14,985 (daily ed. Oct. 23, 1987). 
belief in some threshold constitutional values is a prerequisite for the job. With Democratic Senate majorities recently dominating the confirmation of Republican Supreme Court nominees, these threshold values have included a commitment to the existence of unenumerated rights protected by the Constitution, including the right to privacy, and a respect for stare decisis. ${ }^{5}$ When the dynamic shifted to a Democratic President with Bill Clinton's nomination of Judge Ruth Bader Ginsburg, Democratic senators continued to pursue their agenda, while Republican senators used the occasion to press the nominee to eschew judicial activism and to uphold the death penalty.

In the current era of Supreme Court nominations, commencing with the defeat of Judge Bork in 1987, the Judiciary Committee's role has been described and evaluated in a multitude of ways by critics and supporters. At one extreme is the now familiar, pejorative label "high-tech lynching," pinned on the Committee by then Judge Clarence Thomas. More ponderous is the explanation by Republican Senator Robert Dole that the Committee in 1987 was engaged in an exploration of "the proper scope of the Senate's role in the selection of Supreme Court Justices." 7 The bitter battle over the Bork nomination has been described by some as akin to a national town meeting on the meaning and importance of the Constitution. ${ }^{8}$

The Senate has traditionally defined its role as trying to satisfy itself that a nominee has the "intellectual capacity, competence and temperament," the "good moral character," and the commitment to upholding the Constitution that are required for the Supreme Court. ${ }^{9}$ In the post-Bork era, ${ }^{10}$ however, the confirmation process has also become a means for members of the Senate, especially those who serve on the Judiciary Committee, to try to influence constitutional interpretation.

Senators generally have few opportunities to influence constitutional interpretation. Although they may play a direct role in proposing constitutional amendments, ${ }^{11}$ that method is difficult and cumbersome for senators hoping to correct what they see as the Supreme Court's interpretive mistakes. The Senate has no official means and little other opportunity to influence the outcome of

5. Stare decisis is a Latin term, meaning "[t]o abide by, or adhere to, decided cases." BLACK's LAW DICTIONARY 1406 (6th ed. 1990). The term conveys the concept that law must build on its own precedents.

6. Joan Biskupic, Thomas Drama Engulfs Nation; Anguished Senate Faces Vote, CONG. Q. WKLY. REP., Oct. 12, 1991, at 2948.

7. Hearings Before the Senate Committee on the Judiciary on the Nomination of Robert H. Bork to be Associate Justice of the Supreme Court of the United States, 100th Cong., 1st Sess. 12 (1987) [hereinafter Hearings on the Nomination of Robert H. Bork].

8. See Joseph Biden, Reform of the Confirmation Process, 102d Cong., 2d Sess., 138 Cong. Rec. S8853-901, S8860 (daily ed. June 25, 1992) ("[T]he serious and profound debate that the Bork nomination sparked was among the most important national discussions about our Constitution, its meaning, and the direction of our Supreme Court in this century.").

9. Id. at $\mathrm{S} 8858$.

10. For a more detailed discussion of the "post-Bork era," see infra part III.

11. See U.S. CONST. art. V. 
constitutional cases before the Supreme Court. ${ }^{12}$ Once a Supreme Court nominee is confirmed and sworn in, the Constitution's guarantee of life tenure means the Senate has no subsequent power to influence the new justice's approach to matters of constitutional interpretation. ${ }^{13}$ It is not uncommon for members of the Judiciary Committee to cite life tenure as one justification for their now searching inquiry into the nominee's views and record. ${ }^{14}$

Recasting the recent confirmation process, in part, as an effort to influence constitutional interpretation helps to explain why the process is so emotional and politically volatile. Many reporters who sat through the hearings that preceded Judge Bork's defeat, and many commentators who wrote later, viewed the controversy as being about Bork himself-a personal examination of the man, his outspoken and prolific views, and his combative style and view of the law that seemed to have little place for compassion. ${ }^{15}$ There was something else afoot, however, that had less to do with Bork's identity and more to do with the heart and soul of constitutional interpretation. For example, never before or since in a nomination fight has there been such lobbying and spin control of the news media by interest groups, senators, and, to a lesser extent, the White House. Perhaps for the first time the fight was over more than just one Supreme Court seat. The focus no longer seemed to be simply on who would do the interpreting, as it had been as recently as 1986 when the Judiciary Committee reviewed the nominations of Justice William $\mathrm{H}$. Rehnquist to be Chief Justice ${ }^{16}$ and Judge Antonin Scalia to be an Associate Justice. ${ }^{17}$ Rather, the focus in 1987 was more specifically and philosophically on what path interpretation of the Constitution would take. For the first time in recent times, senators were

12. The Senate does, on occasion, file an amicus curiae brief when it is not a party to a Supreme Court case. Senators also file amici briefs occasionally, usually as a group. The influence of these briefs depends very much on the circumstances and is difficult to measure, although a number of writers have tried. See generally Bruce J. Ennis, Effective Amicus Briefs, 33 CATH. U. L. REV. 603 (1984).

13. Supreme Court Justices have life tenure during "good Behaviour." U.S. CONST. art. III, § 1. While they may be influenced by amici briefs, discussed supra note 12, Justices are, of course, not subject to recall or other reprimand based on their constitutional decisions.

14. Hearings Before the Senate Committee on the Judiciary on the Nomination of David H. Souter to be an Associate Justice of the Supreme Court of the United States, 101st Cong., 2d Sess. 28 (1990) [hereinafter Hearings on the Nomination of David H. Souter] (Senator Dennis DeConcini, an Arizona Democrat, told nominee Judge Souter that "[o]nce the President appoints and the Senate confirms, a Supreme Court nominee never has to look back.").

15. See, e.g., Calvin R. Massey, Getting There: A Brief History of the Politics of Supreme Court Appointments, 19 HASTINGs Const. L.Q. 1, 6 (1991) (Bork's defeat is listed under the subhead "Opposition to the Nominee's Political Views.").

16. Rehnquist's nomination to be Chief Justice was approved by the Senate on September 17, 1986, by a vote of $65-33$. 132 CoNG. REC. 23,803 (1986). Much of the focus of the hearings was on Rehnquist as an individual and lawyer, including questions raised about a restrictive covenant on his Vermont home, his alleged harassment of minority voters in Arizona in the $1960 \mathrm{~s}$, his health and willingness to disclose medical problems, his policy on recusal in Supreme Court cases, and his authorship as a law clerk of a memo for Justice Robert Jackson in the case of Brown v. Board of Education, 347 U.S. 483 (1954), advocating that the "separate but equal" approach of Plessy v. Ferguson, 163 U.S. 537 (1896), be retained.

17. Scalia's nomination was approved on September 17, 1986, 98-0. 132 CoNG. REC. 23,813 (1986). Scalia's refusal to discuss most substantive constitutional matters with the committee meant that the focus was largely on his qualifications for and approach to the job. 
prepared to mount a campaign against a nominee, not because of lack of qualifications, corruption, or character flaws, but because of the nominee's likely impact on our understanding of the Constitution.

There is also evidence that viewing confirmation hearings as a form of constitutional interpretation has met with some success. ${ }^{18}$ Most clearly, Justices David H. Souter, Anthony M. Kennedy, and Clarence Thomas, as nominees, acknowledged the constitutional importance placed on stare decisis by Democratic members of the Judiciary Committee. ${ }^{19}$ All three men, elevated to the Supreme Court from federal appeals courts, also recognized the need to assure the Judiciary Committee that they believed in the existence of unenumerated fundamental rights in the Constitution, specifically the right to privacy. ${ }^{20}$ It is fair to wonder how many of the three unequivocally held that view before their Supreme Court nominations.

If there is any clear message that results from this view of the modern confirmation process, it is that no Supreme Court nominee may appear before the Judiciary Committee today and expect to be confirmed without being willing to make a commitment to the existence of some form of constitutional right of privacy. While nominees may differ about the scope and basis of this right, they must regard the right as no less broad than that first recognized by the Supreme Court in Griswold v. Connecticut. ${ }^{21}$ Justice Ginsburg made this commitment as well, although this was less surprising since she was known to be a moderate Democrat rather than a conservative Republican.

There are, of course, differences in how the nominees implement the right to privacy or the role of stare decisis once they are confirmed. It seems unlikely, for instance, that Democratic senators on the Judiciary Committee take any comfort in the votes and opinions of Justice Clarence Thomas, despite his having offered these senators some recognition of their concerns in his confirmation hearings.

Viewing the confirmation process as an exercise in constitutional interpretation also helps to eliminate some of the confusion about the Senate's proper role in the confirmation process. Questions asked of nominees that explore their constitutional philosophies and approaches to different parts of the Constitution

18. Using the process to influence constitutional interpretation has not been the province of only one political party or ideology. Although Democrats have met with more success in this endeavor, conservative Republicans tried a similar approach in 1981 during the confirmation hearings of Sandra Day O'Connor. See infra text accompanying notes 44-47.

19. Hearings Before the Senate Committee on the Judiciary on the Nomination of Anthony $M$. Kennedy to be Associate Justice of the Supreme Court of the United States, 100th Cong., 1st Sess. 135-136 (1987) [hereinafter Hearings on the Nomination of Anthony M. Kennedy]; Hearings on the Nomination of David H. Souter, supra note 14, at 67-68; Hearings Before the Senate Committee on the Judiciary on the Nomination of Judge Clarence Thomas to be Associate Justice of the Supreme Court of the United States, 102d Cong., 1st Sess. pt. I, 134-35 (1991) [hereinafter Hearings on the Nomination of Clarence Thomas].

20. Hearings on the Nomination of Anthony M. Kennedy, supra note 19, at 88, 164; Hearings on the Nomination of David H. Souter, supra note 14, at 54; Hearings on the Nomination of Clarence Thomas, supra note 19 , at 127.

21. 381 U.S. 479 (1965). 
make more sense in this context than in some other explanations of the Senate's role. $^{22}$ Some scholars have urged precisely this approach on the Senate as a way of bringing consistency to the Senate's method of confirming Supreme Court nominees. ${ }^{23}$

This article explores the confirmation process as a form of indirect constitutional interpretation by the Senate, taking into account the importance of the distinctive Zeitgeist that marks each nomination. ${ }^{24}$ To do so, this article draws in part on the author's recollection of recent confirmation struggles. Part II looks at select Supreme Court nominations and concludes that the post-Bork era model of the Senate using Supreme Court confirmations as a mode of constitutional interpretation is a new model, not the customary approach. Part III chronicles the most recent experience with confirmation hearings, particularly the nominations of Justices Kennedy, Souter, Thomas, and Ginsburg. Part IV examines the efficacy of this approach as a means of influencing constitutional interpretation. There are a number of variables that must be considered, including external forces such as a division of political party control between the White House and the Senate, and the willingness, actual and perceived, of senators to fight if they are not satisfied with their ability to influence the nominee's view of the Constitution. Part V concludes that, although the success may vary depending on the circumstances of each nomination, the Judiciary Committee has succeeded in framing the constitutional dialogue and defining core constitutional values on which nominees must focus.

22. Senators have typically justified their questions as necessary to exercise their "advice and consent" role mandated by Article II, Section 2, Clause 2 of the U.S. Constitution. However, if this role has traditionally meant assessing a nominee's fitness for office, the justification does not fully explain the need for questions that focus on specific cases or specific issues of constitutional interpretation and methodology.

23. Laurence H. Tribe, God Save This honorable Court 131 (1985) ("A concerted, collective effort by the upper house of Congress to articulate a vision of the Constitution's future, and to scrutinize potential justices in that vision's light, is of course the ideal.").

24. "Zeitgeist" is a German word meaning the spirit of the time or the characteristic outlook of the period. WEBSTER'S THIRD NEW INTERNATIONAL DICTIONARY 2657 (1971). A casual reader of the proceedings of the Judiciary Committee might wonder how to tell one set of confirmation hearings from another. The answer cannot be found in the transcripts but in the confluence of the questions and responses, and the spirit and political ambience of a nomination. The substantive questions posed by senators may sound very similar, even identical, from one hearing to the next. The overall context varies widely, however, and it is possible to point to specific nominations and reach conclusions, based on the Zeitgeist, about whether the confirmation turned on the identity of the individual or on substantive constitutional issues. Traditionally, although some constitutional questions may have been asked, the answers scarcely mattered. There was no sense that a nominee would be confirmed or not based on the answers to these constitutional questions. This is largely because the Senate focused on the ability of the hearing process to expose scandal, but senators had not yet realized the potential of the confirmation hearings as a substantive constitutional dialogue. Identifying the Zeitgeist, then, differentiates between facially similar confirmation hearings. 


\section{II}

\section{AN Historical ViEW}

The confirmation of Ruth Bader Ginsburg brought to 107 the number of persons who have served on the Supreme Court, including the members sitting in the 1993 Term. $^{25}$ In addition, 28 nominations have been rejected, withdrawn or not acted upon, or squelched by the White House prior to submission to the Senate. Those numbers yield a current confirmation rate for Supreme Court nominees of 79.3 percent.

Historically, the confirmation process has focused on a range of issues. The issues relevant to the President and the Senate have sometimes varied, but rarely has the focus been on the future direction of constitutional interpretation. Professor Henry Abraham, one of the leading students of the nomination and confirmation process, has identified seven reasons for Senate rejection of Supreme Court nominees, ranging from opposition to the President who made the appointment to special interest group pressures. ${ }^{26}$ Only one of the seven reasons reflects a concern with constitutional interpretation. He described it as "senatorial opposition to the record of the incumbent Court which the nominee seemed to support."27 The example he cited was President Grant's nomination of his attorney general, Ebenezer R. Hoar, who was denied a seat on the Supreme Court in 1870 , by a Senate vote of $33-24 .^{28}$

The direction of the Court's jurisprudence was of paramount concern in other instances, but the concern primarily influenced the President rather than the Senate. The most obvious such instances were President Franklin D. Roosevelt's "court-packing" proposal and the several nominations that followed the demise of that legislation. ${ }^{29}$ Here, however, the focus on the direction of constitutional interpretation was clearly Roosevelt's.

Concern about the direction of interpretation has played a minor part in some more recent Supreme Court nominations. Evidence exists that suggests that at least some of the opposition to the proposed elevation of Justice Abe Fortas to be Chief Justice in 1968 was based on the Court's decisions in the areas

25. Supreme Court terms open the first Monday in October and close when the Court's business is finished, usually in late June or early July. 28 U.S.C. $\$ 2$ (1988); SUP. CT. R. 3.

26. See Henry Abraham, "A Bench Happily Filled:" Some Historical Reflections on the Supreme Court Appointment Process, 66 JUDICATURE 282 (1983).

27. Id.

28. Id. But see Massey, supra note 15, at 5 (arguing that Hoar was rejected "because he sought to eliminate political patronage and, even worse, had opposed Andrew Johnson's impeachment").

29. For a discussion of the motivation behind the court-packing proposal, see William E. Leuchtenberg, The Origins of Franklin D. Roosevelt's “Court-Packing” Plan, 1966 SUP. CT. REV. 347. Roosevelt proposed to increase the size of the Court in 1937. This was in direct response to his frustration at the Court's invalidating many central legislative pieces of the New Deal. The court-packing legislation met with widespread opposition and was recommended for defeat by the Senate Judiciary Committee.

Meanwhile, Roosevelt was able to achieve his objective through replacement of retiring Justices, replacing Willis Van Devanter with Hugo L. Black in 1937 and George Sutherland with Stanley F. Reed in 1938. 
of criminal procedure and obscenity. ${ }^{30}$ Fortas was being blamed for the direction of the Court on which he served, however, a different proposition from influencing the constitutional values of a new nominee who may be about to take his or her place on the Court.

During the debate on Fortas on the Senate floor, Southern Democratic Senator Sam Ervin criticized Fortas repeatedly for being "among the judicial activists who regard the Constitution as something in the nature of a quivering legal aspen leaf, whose meaning trembles and changes when sitting Supreme Court Justices waiver in mind and new Supreme Court Justices ascend the Bench." 31 Ervin also criticized major criminal procedure decisions of the Court such as Miranda v. Arizona ${ }^{32}$ and faulted Fortas for joining them. These decisions, he said, "permit multitudes of murderers, rapists, burglars, robbers and thieves to go unwhipped of justice." 33 Republican Senator Strom Thurmond also attacked the Court, and Fortas for being a part of it. ${ }^{34}$

The Fortas nomination was withdrawn after the Senate deadlocked in a filibuster by Republicans and Southern Democrats, and Fortas later resigned from the Court for reasons involving suggestions of scandal in his personal finances and having no relation to the Court's direction and jurisprudence. ${ }^{35}$

The Fortas experience was unusual because he was already on the Court. The more traditional approach has been to focus on characteristics related to the individual nominee. ${ }^{36}$ The unsuccessful nominations of Judges Clement Haynsworth, Jr., and G. Harrold Carswell, ${ }^{37}$ and the successful nominations of Judge Harry A. Blackmun, ${ }^{38}$ Lewis F. Powell, Jr., and William H. Rehnquist ${ }^{39}$

30. See Attempt to Stop Fortas Debate Fails By 14-Vote Margin, 1968 ConG. Q. AlmanaC 531 ("Decisions in the area of criminal procedural law and obscenity were singled out for bitter criticism."). Much of the opposition to Fortas was based on other factors, such as cronyism due to his closeness to President Lyndon Johnson, the impropriety of his continuing to give Johnson advice, and his acceptance of $\$ 15,000$ in funds raised from private business to conduct a nine-week seminar at American University's law school.

31. 114 CONG. REC. 28,579 (1968).

32. 384 U.S. 436 (1966) (requiring exclusion of confessions obtained from suspects in custody prior to informing them of their rights).

33. 114 CONG. REC. $28,579-80$ (1968).

34. Senator Thurmond said, "I believe the Supreme Court's decisions with regard to pornography have encouraged its use and extended the extremity of its form ... the Court has given such filth a respectability it does not deserve." He also stated that "Justice Fortas has shown, by his record on the Supreme Court, that he is not only content with the Court's trend in these cases, but also that he is willing to take these trends to further extremes." 114 CONG. REC. 28,772 (1968).

35. For a full discussion of his resignation, see LAURA KALMAN, ABE FORTAS: A BIOGRAPHY 36786 (1990).

36. The nomination of Judge Warren Burger to be Chief Justice was approved by the Senate on June 9 1969, by a vote of 74-3. 115 CONG. REC. 15,195 (1969). Burger's nomination is an example of the more traditional approach to Senate confirmation. See Warren Court Record, Burger Opinions Compared, 1969 Cong. Q. Almanac 129.

37. Judge Haynsworth was rejected by the Senate on Nov. 21, 1969, by a vote of 55-45. 115 CoNG. REC. 35,396 (1969). Judge Carswell was defeated by the Senate on April 8, 1970, by a vote of 51-45. 116 CONG. REC. 10,769 (1970).

38. Judge Blackmun was approved by the Senate on May 12,1970 , by a vote of $94-0$, little more than a month after Carswell's defeat. 116 CoNG. REC. 15,117 (1970). 
are examples of the traditional approach. The focus of their hearings was largely, although not always exclusively, on the identity and character of the nominees themselves, rather than on their likely impact on the Court and the Constitution. ${ }^{40}$ Of these five nominees, Rehnquist was the most noticeably questioned about his approaches to constitutional interpretation and to major issues of the time, but there were also concerns of a more traditional character. Traditional questions included whether he had ever been a member of the rightwing John Birch Society, an allegation that he denied in an affidavit. ${ }^{41}$

The 1975 confirmation hearings of Judge John Paul Stevens, selected by President Ford to replace Justice William O. Douglas, demonstrates that the Zeitgeist did not then permit the Judiciary Committee to use a nominee's constitutional beliefs to reject the nomination. Like nominees in the post-Bork era, Stevens was asked how he viewed the role of stare decisis in constitutional decisions. He replied, "I would feel bound, but not absolutely 100-percent bound .... I think there are occasions, particularly in constitutional adjudication, where it is necessary to recognize that a prior decision may have been erroneous and should be reexamined."42 The questioning of Stevens mattered little, however, in the Zeitgeist of his nomination. His confirmation was never in doubt because he was a respected judge on the U.S. Court of Appeals for the Seventh Circuit and was regarded, to the relief of many moderates and liberals who feared a conservative appointment, as a high-caliber selection by President Ford. His nomination also came in an era before the Senate recognized its ability to have meaningful constitutional discourse with nominees. Stevens was unanimously approved by the Senate. ${ }^{43}$

39. Nominated and sworn in together, Powell and Rehnquist met with different Senate reactions. Powell was confirmed by the Senate on December 6, 1971, by a vote of 89-1. 117 CONG. REC. 44,857 (1971). Rehnquist was approved by the Senate four days later on December 10, 1971, by a vote of 68-26. 117 CONG. REC. 46,197 (1971).

40. For a full discussion of the Haynsworth hearings, see Senate Rejects Haynsworth Nomination To Court, 1969 CONG. Q. AlmaNAC 337 (Haynsworth was questioned extensively about stock he owned and his service on corporate boards, resulting in possible conflicts of interest in cases on which he sat, and third parties testified that he was anti-labor). For a full discussion of the Carswell hearings, see Carswell Nomination to Court Rejected by Senate, 1970 CONG. Q. AlMANAC 154 (although some opposition was based on Carswell's characterization of himself as a "strict constructionist," most controversy focused on whether he was a racist and a segregationist and on whether he was sufficiently competent as a lawyer and judge to serve on the Supreme Court). For a full discussion of the Blackmun hearings, see Blackmun Unanimously Confirmed For Supreme Court, 1970 CoNG. Q. ALMANAC 163 (although Blackmun answered a few questions about his views of the Constitution, the truly adversarial questions focused on his stock holdings and plans to avoid conflicts of interest). For a full discussion of the Powell and Rehnquist hearings, see Court Nominees: Powell and Rehnquist Confirmed, 1971 CoNG. Q. ALMANAC 851 (Both nominees underwent some questioning about their approach to constitutional interpretation, but Powell was also questioned about his attitudes toward school desegregation and about his stock portfolio as a possible source of conflicts-of-interest while Rehnquist was questioned more about his role as a Justice Department lawyer and about his attitudes toward civil rights.).

41. Court Nominees: Powell and Rehnquist Confirmed, supra note 40, at 855.

42. Hearings Before the Senate Committee on the Judiciary on the Nomination of John Paul Stevens, of Illinois, to be an Associate Justice of the Supreme Court of the United States, 94th Cong., 1st Sess. 40 (1975).

43. Judge Stevens was confirmed by the Senate, 98-0, on December 17, 1975.121 CoNG. REC. $41,128(1975)$. 
The post-Bork era of Supreme Court confirmations obviously did not spring fully-developed as a political or constitutional methodology from the Bork hearings in 1987. The Fortas hearings in 1968 and the first Rehnquist hearings in 1971 helped to foreshadow the evolution of confirmation hearings. The hearings on Sandra Day O'Connor also offered a variation on this theme, a proving ground of sorts.

The nomination process for Justice O'Connor, an Arizona state court judge selected by President Reagan in 1981, bears some similarities to the confirmation hearings in the post-Bork era. There is, however, one critical difference: the Zeitgeist. There was never any question about whether O'Connor would be confirmed. ${ }^{44}$ This was especially true since she was the first woman ever nominated for the Supreme Court and to oppose her nomination would have cost senators the political support of women. Thus, as with some earlier examples, the substantive questions of constitutional interpretation put to her lacked the force of a possible rejected nomination. As in the case of Stevens, the questions were asked but senators did not appear to be seriously evaluating their support for her based on the answers.

Nevertheless, Justice O'Connor's confirmation bears further examination because it reveals the interest on both sides of the political aisle in influencing the course of constitutional decisionmaking. The Democrats on the Judiciary Committee, who were the minority party since they lost control of the Senate in the 1980 election, asked O'Connor the types of questions that marked later hearings. For example, Democratic Senator Patrick Leahy sought, with some success, to secure from the nominee a commitment to the right to privacy:

Leahy: Do you have any views on that right within the Constitution?

O'Connor: The Court seems to have established that there is such a right.

Leahy: How do you feel on that?

O'Connor: I accept the fact that the Court has established that .... ${ }^{45}$

The Democrats were not alone in seeking to satisfy themselves quite specifically about the nominee's views, not only on privacy but on stare decisis and a range of other issues of the day. Three conservative Republican senators, although members of the Senate's majority party and philosophically aligned with the Reagan electoral landslide, also sought assurances from O'Connor about moral issues. The three were Jeremiah Denton, John East, and Charles Grassley. Senator Denton, for example, pressed O'Connor repeatedly for her views on abortion and managed to elicit rather candid and highly unusual personal observations, although answers that were short of the commitments that he sought:

44. She was unanimously approved by the Senate, 99-0, on September $21,1981.127$ CONG. REC. 21,375 (1981).

45. Hearings Before the Senate Committee on the Judiciary on the Nomination of Judge Sandra Day O'Connor of Arizona to Serve as an Associate Justice of the Supreme Court of the United States, 97th Cong., 1st Sess. 171-72 (1981). 
Denton: Under what conditions do you now feel that abortion is not offensive? O'Connor: [F]or myself, it is simply offensive to me. It is something that is repugnant to me and something in which I would not engage. ${ }^{46}$

$* * * *$

Denton: However, where the family is in existence and the 13-year-old wants an abortion, would you be in favor of her being required under normal circumstances to have the parents notified, and so forth?

O'Connor: [A]gain[,] without expressing a view that could be interpreted as my position on any legal issue that would come before the court ...., I would simply say that I would want to have the child consult the parents and have the parents work with the child on that issue. ${ }^{47}$

If the O'Connor confirmation hearing resembled the post-Bork model, it was little more than a precursor. In 1986, when Justice Rehnquist was nominated to be Chief Justice and Judge Antonin Scalia was nominated to the Court, the more traditional confirmation questions seemed to dominate, although there was once again a hybrid struggle over Rehnquist that resembled his first confirmation in 1971. Liberal Democratic senators and liberal interest groups mounted opposition to Rehnquist, both on the basis of his conservative record as a Justice, and on more personal, character questions, such as his health and his willingness to reveal medical problems, and whether he had harassed minority voters as a poll watcher in Arizona in the 1960s. Much of this opposition, to the extent that it was based on his constitutional views, represented a mirror image of the Fortas nominations: he was being examined for his previous tenure and questioned by liberal opponents who were upset about the direction of the Court. In the case of Scalia, the Zeitgeist was clear: if senators had begun to appreciate the possibility for constitutional dialogue, they readily abandoned it when he proved unwilling to answer questions, and his confirmation was never in any doubt.

\section{III}

\section{BORK, THE POST-BORK ERA, AND THE CONSTITUTION}

The fight over the Bork nomination has been amply debated by all sides ${ }^{48}$ and a detailed analysis is beyond the scope of this article. The long-term significance of the Bork confirmation struggle, however, is that it departed from what was then the norm, and may in turn have established a new norm for confirmation hearings. ${ }^{49}$ It was a truly transformative event, a confirmation

46. Id. at 125 .

47. Id. at 247 .

48. See generally Robert H. Bork, THe Tempting of AMERICA: The Political Seduction OF THE LAW (1990); ETHAN BRONNER, BATTLE FOR JUSTICE: HOW THE BORK NOMINATION SHOOK AMERICA (1989); MARK GITENSTEIN, MATTERS OF PRINCIPLE: AN INSIDER'S ACCOUNT OF AMERICA'S REJECTION OF ROBERT BORK'S NOMINATION TO THE SUPREME COURT (1992); PATRICK MCGUIGAN \& DAWN WeYRICH, NiNTH JusticE: THE FIGHT FOR BORK (1990); MICHAEL PERTSCHUK \& WENDY SChaETZEL, The PEOPle Rising: The CAMpaign Against THE Bork Nomination (1989).

49. Stanford political scientist David Danelski made a similar point when he observed that "[e]ven though the history of judicial nominations does not justify ideological rejection of Supreme Court nominees, that does not mean that such rejection is without constitutional justification." David J. 
hearing that occupies five inch-and-a-half thick volumes of records and transcripts, each volume more than twice the thickness of O'Connor's or Scalia's single-volume hearings. The Bork nomination was the first occasion in modern times on which the Senate rejected a nominee because his confirmation might move constitutional interpretation in a direction different from that desired by the majority of senators. ${ }^{50}$ It is this approach, its effectiveness and durability, that is at the heart of the post-Bork model for Supreme Court confirmations.

\section{A. Anthony M. Kennedy}

The nomination of Judge Anthony M. Kennedy of the U.S. Court of Appeals for the Ninth Circuit was the first to be defined by the post-Bork model. ${ }^{51}$ Democrats who controlled the Senate had to prove that, having defeated Bork, Kennedy was not simply Bork without a beard. If the Bork hearings were to hold any transcendent meaning, the Democratic Senate would have to refuse to confirm a nominee who shared Bork's disdain for the doctrine of unenumerated rights in the Constitution, specifically his rejection of an implied right to privacy. ${ }^{52}$ The Democratic senators knew that imposing this standard on Kennedy's confirmation would be no small feat because their resources and energies were exhausted from the bitter, difficult four-month Bork struggle. Still, the Committee wanted to preserve the precedent set by the Bork hearings.

Senator Joseph Biden, a Delaware Democrat and Judiciary Committee Chairman, lost no time at the start of the Kennedy hearings outlining his view of the exact nature of the legacy of the Bork nomination. He said:

[W] must know the nominee's constitutional views, and state clearly to the nominee our own perspective on constitutional interpretation. To uphold these standards, we must begin by insisting that every Supreme Court nominee understand and accept a

Danelski, Ideology As A Ground for the Rejection of the Bork Nomination, 84 Nw. U. L. REv. 900, 920 (1990).

50. There remains some debate about how different Bork's direction and the Senate's would really have been. Bork has argued consistently that his record on, and writings and views about, constitutional interpretation were misrepresented and distorted by liberal interest groups and liberal senators. See BORK, supra note 48, at 9.

51. President Reagan initially nominated Judge Douglas H. Ginsburg of the U.S. Court of Appeals for the D.C. Circuit after Bork was defeated, but Ginsburg withdrew after revelations about his use of marijuana while a Harvard Law School professor. Had he remained the nominee, Ginsburg no doubt would have been subjected to the first test of the post-Bork model.

52. There were other bellwether issues of importance in the Bork hearings that became part of the pattern repeated with Kennedy and subsequently. For example, a few senators questioned Bork about the First Amendment and whether it should be narrowly limited to political speech or should encompass a broader range of communication about cultural, scientific, literary, and social matters.

Bork had espoused the narrower approach in a law review article that became a focus of his hearings, Neutral Principles and Some First Amendment Problems, 47 IND. L.J. 6, 20 (1971). At his hearings, however, Bork said his views had evolved to conform to the Supreme Court's approach of the time. Hearings on the Nomination of Robert H. Bork, supra note 7, at 274.

Another line of inquiry that repeated itself, most often from Arizona Senator DeConcini, was about a nominee's commitment to the treatment of gender discrimination as appropriate for the middle tier scrutiny equal protection standard of Craig v. Boren, 429 U.S. 190 (1976). See, e.g., Hearings on the Nomination of Robert H. Bork, supra note 7, at 255-58, 391-96. 
number of basic constitutional principles, among them the separation of powers, unenumerated rights, equal protection for minorities and for women, for all citizens, and due process of the law, and the precious rights protected by the first amendment. It seems to me the Senate should, properly, explore further each of these issues, and it is equally reasonable to expect every nominee to state to the Senate the general ... criteria that he, or she, would use to apply these fundamental principles. $^{53}$

Kennedy, too, had to make some difficult choices. First he had to decide how loquacious and forthright to be in answering the Judiciary Committee's questions. Bork had made a threshold judgment that he would discuss constitutional interpretation at great length with the Judiciary Committee. ${ }^{54}$ That was not the historical practice. ${ }^{55}$ Indeed, Bork later regretted that his extensive discussion of constitutional issues came to be seen as the model for other nominees. ${ }^{56}$

To suggest that Kennedy merely acquiesced to the model is to give him too little credit. He conveyed a clear impression to observers at the time of his confirmation hearing, in December 1987, and to senators in his private meetings with them in the weeks before the hearings, that he intended to provide forthright answers that would alleviate the concerns of senators about constitutional interpretation. He made it clear to senators and their staffs that his views were not those of Bork, and that they should look forward to satisfactory answers. $^{57}$

Obviously an equally important issue for the senators was what questions to ask to make clear that a sudden change in constitutional interpretation was not desirable. For the nominee, the issue was what answers to provide. Democratic senators chose to follow what had proved to be the politically effective pattern of questioning in the Bork hearings: They tried to focus their constitutional

53. Hearings on the Nomination of Anthony M. Kennedy, supra note 19, at 23-24.

54. In a July 1987 conversation with this author, while Bork's nomination was pending and before his hearings had begun, Bork explained that he felt he had to go to unusual lengths to explain his views to the committee because he had written and spoken so extensively on a broad array of constitutional and statutory issues over such a prolonged period.

55. Harlan F. Stone was the first nominee to appear before the Senate Judiciary Committee, and that was in 1925. Although Stanley Reed appeared in 1938, Felix Frankfurter in 1939, Frank Murphy in 1940, and Robert Jackson in 1941, the practice of appearing still did not become routine until the 1950s, and the practice of answering detailed questions about constitutional philosophy was even more rare. See generally William G. Ross, The Questioning of Supreme Court Nominees at Senate Confirmation Hearings: Proposals For Accommodating the Needs of the Senate and Ameliorating the Fears of the Nominees, 62 TUL. L. REV. 109 (1987).

56. In a speech to the American Jewish Committee in Chicago, after his defeat, Bork said, "What I did is now being taken as a precedent for future nominees, and I feel that it should not be taken as a precedent." This excerpt is quoted in GITENSTEIN, supra note 48, at 319.

57. In the course of covering the nomination for The Wall Street Journal, the author was told by aides to several Democratic senators that Kennedy was taking steps in private meetings to allay their fears and to assure them that his approach both to the hearings and to the Constitution differed markedly from Bork's. Additionally, Senator Paul Simon, an Illinois Democrat and Senate Judiciary Committee member recalls that "Judge Kennedy did a good job of what the White House calls 'schmoozing Senators." PAul Simon, AdVICE AND CONSENT: ClaRENCE THOMAS, ROBERT BorK AND THE INTRIGUING HISTORY OF THE SUPREME COURT'S NOMINATION BATTLES 67 (1992). 
concerns on the widely acclaimed general right to privacy and the existence of rights that are not spelled out in the Constitution, rather than focusing specifically on the more divisive status of Roe $v$. Wade ${ }^{58}$ and the right to abortion. Instead of pressing for views on each landmark precedent that they held dear, they probed more broadly about stare decisis: about how it works, when deference to precedent is appropriate, and what factors pertain to such obeisance. ${ }^{59}$ They asked time and again about the nominee's view of the Ninth Amendment, ${ }^{60}$ thereby assuring themselves of a comparison to Bork, who said the meaning of the Ninth Amendment could not be determined with any greater clarity than words hidden beneath an "ink blot." "61

For his part, Kennedy was adept at providing assurances that he operated from the same broad fundamental constitutional premises as the Democratic senators. Yet he never overstepped the bounds of propriety that keep a nominee from commenting too specifically on issues that may come before the Supreme Court. He set a mild-mannered tone that was neither evasive nor belligerent, giving Democratic senators much to digest. For example, in response to questioning by a number of Democrats, he said, "I think that the concept of liberty in the due process clause is quite expansive, quite sufficient, to protect the values of privacy that Americans legitimately think are part of their constitutional heritage." ${ }^{2}$

Questions and answers at this level of generality were most effective. He declined to get any more specific, not only about Roe, but also about the foundational privacy case, Griswold $v$. Connecticut ${ }^{63}$ in which the Supreme Court first recognized a fundamental right to marital privacy. But he was most reassuring on the Ninth Amendment, suggesting to Senator Biden, "It seems to me the Court is treating it as something of a reserve clause, to be held in the event that the phrase 'liberty' and the other spacious phrases in the Constitution appear to be inadequate for the Court's decision." ${ }^{64}$

Lest this scenario look so harmonious that it appears nothing more than a charade, it should be repeated that the Democrats had much at stake in this confirmation. Kennedy would replace Justice Powell, long the crucial fifth or "swing" vote for much of the constitutional jurisprudence that mattered to liberal and moderate Democrats. The effort to influence Kennedy's constitutional view was, therefore, very real. While it is true that the nomination had its own

58. 410 U.S. 113 (1973).

59. For a discussion of the types of questions and answers in the Kennedy confirmation hearing, see BRONNER, supra note 48, at 337; see also GITENSTEIN, supra note 48, at 317.

60. U.S. CONST. amend. IX ("The enumeration in the Constitution, of certain rights, shall not be construed to deny or disparage others retained by the people.").

61. The reference to the "ink blot" came in an exchange at Bork's hearings with Senator Dennis DeConcini, and is quoted in GITENSTEIN, supra note 48, at 230.

62. Hearings on the Nomination of Anthony M. Kennedy, supra note 19, at 164.

63. 381 U.S. 479 (1965).

64. Hearings on the Nomination of Anthony M. Kennedy, supra note 19, at 87, 88. 
Zeitgeist, including an expectation of confirmation, ${ }^{65}$ Democratic senators and their aides were insistent that if Kennedy had not heard the constitutional message of the Bork hearings, he could face a real fight.

It must be noted that the Democrats were not the only ones fighting for the constitutional conscience of Kennedy. A few conservative Republicans, most notably Senator Gordon Humphrey of New Hampshire, were concerned by aspects of Kennedy's opinion in Beller v. Middendor $f^{66}$ upholding the Navy's discharge of servicemen for homosexual activity. In his opinion, Kennedy wrote:

We recognize, as we must, that there is substantial academic comment which argues that the choice to engage in homosexual action is a personal decision entitled, at least in some instances, to recognition as a fundamental right and to full protection as an aspect of the individual's right to privacy. ${ }^{67}$

Senator Humphrey expressed alarm at this sentence and observed, "My goodness, you can find academic comment to justify almost anything." ${ }^{68}$ As party loyalists, however, Republican senators were in a weak position to try to influence Kennedy, since their votes for him were virtually assured.

Kennedy was confirmed February 1, 1988, by an unanimous Senate, 97-0. ${ }^{69}$

\section{B. David H. Souter}

Judge David Souter of the U.S. Court of Appeals for the First Circuit was far more of an enigma to the Senate when he was nominated by President George Bush to succeed Justice William J. Brennan, Jr. He was a mystery because he had written virtually nothing on major federal constitutional questions. He had demonstrated his competence and intelligence during twelve years as a state trial judge and state supreme court justice in New Hampshire, but his experience as a federal judge was limited to three months on the First Circuit.

The political dynamic was no less significant than in the case of Kennedy: Souter was thought likely to be a Reagan-Bush conservative replacing the Court's liberal institutional memory and leader. Again, as in the Kennedy nomination, the Zeitgeist of Souter's confirmation was an expectation that he would be approved. This was fostered by the presence of a new confirmation hearing phenomenon, the existence of a Senate mentor. Republican Senator Warren Rudman, Souter's close friend, and former boss, was on hand to assure senators that Souter embraced moderate, mainstream constitutional values, not those held by the most conservative elements of the Republican Party. This

65. It would be an error to leave the impression that there was not also a personal element to the Kennedy confirmation. Emotionally exhausted and politically drained from the Bork nomination, senators of both parties were not looking for another fight and went into the process hoping the nominee would succeed. It is difficult to assess whether this means Kennedy was subjected to easier scrutiny, since in the post-Bork era the level of scrutiny was raised from the previous norm.

66. 632 F.2d 788 (9th Cir. 1980), cert. denied sub nom. Beller v. Lehman, 454 U.S. 855 (1981).

67. Id. at 809 .

68. Hearings on the Nomination of Anthony M. Kennedy, supra note 19, at 177.

69. 134 CONG. REC. S516 (daily ed. Feb. 3, 1988). 
advance work went a long way toward assuring senators that Souter was not the unusual, ascetic character that some news media profiles had made him appear to be..$^{70}$

Since so little was known about him, and since the direction of Supreme Court constitutional interpretation hung in the balance, he nevertheless faced tougher grilling than Kennedy. Once again, Democratic senators concluded that the effort to send Souter a message should generally be in broader terms, focusing on privacy, the Ninth Amendment, and stare decisis. Questions along those lines started right in, and Souter proved quick, candid, and appropriately committed to the broad contours of current constitutional theory. His very first answer of the hearings, to Senator Biden, was, "I believe that the due process clause of the 14th Amendment does recognize and does protect an unenumerated right of privacy." ${ }^{\prime 11} \mathrm{He}$ also recognized that the Ninth Amendment, although uncertain in its contours, was an assertion of unenumerated rights that had to be free from government interference. ${ }^{72}$

Far less productive were more specific questions asked of the nominee. When Souter acknowledged a fundamental right to decide whether to use birth control or to become pregnant, Biden asked whether a woman has the same "constitutional right to choose not to become pregnant" if she uses birth control and it fails. ${ }^{73}$ Obviously, the way to choose not to be pregnant at that point is abortion, and Souter declined to answer, noting that there was "not only a possibility, but a likelihood that the Court may be asked"74 to reconsider its decision in Roe $v$. Wade. ${ }^{75}$

Once again, conservative senators also sought to satisfy themselves, but with no real threat to back up their inquiry, that Souter would be a Justice of conservative principles, not one co-opted by the liberal approach to the Constitution.

Mark Gitenstein, former Chief Judiciary Committee Counsel to Senator Biden, summed up the effect of the Kennedy and Souter confirmations on the constitutional interpretation of the judges as follows:

The nominations of Anthony Kennedy by Ronald Reagan and of David Souter by George Bush ratify a new conventional wisdom about Supreme Court nominees. Both deliberately distanced themselves from Bork's jurisprudence because they recognized that Americans do believe they have certain unwritten rights. The Senate will reject any nominee who does not embrace that philosophy or who suggests that the Warren Court was wrong in recognizing those fundamental rights. ${ }^{76}$

70. See Mary McGrory, A Tale of 2 Nominees, WASh. Post, Aug. 1, 1991, at A2; Ann Devroy \& Sharon LaFraniere, Danforth's Backing Was Key to President's Choice of Thomas, WASH. POST, July 3 , 1991, at A1. See also SIMON supra note 57, at 76 ("Senator Rudman reduced the possible negative votes by coming around to each of us with the reassuring words, 'Take my word for it. He'll be okay."').

71. Hearings on the Nomination of David $H$. Souter, supra note 14, at 54.

72. Id. at 55 .

73. Id. at 59 .

74. Id.

75. 410 U.S. 113 (1973).

76. GITENSTEIN, supra note 48 , at 16 . 
Souter was confirmed by the Senate, by a vote of $90-9$, on October $2,1990 .^{7}$

\section{Clarence Thomas}

The hearings for Judge Clarence Thomas of the U.S. Court of Appeals for the District of Columbia Circuit, nominated to replace Justice Thurgood Marshall in 1991, exemplify both the old and the new traditions in Senate confirmation hearings. The September 1991 hearings followed the now established pattern of Democrats trying to send strong, clear messages to the nominee and seeking assurances about his commitment to fundamental constitutional values. ${ }^{78}$ But with an early October date set for the Senate to vote, and confirmation seen as likely although not without significant opposition, the sexual harassment allegations by Professor Anita Hill exploded onto the scene and eclipsed any further debate over constitutional interpretation. ${ }^{79}$

Despite this electrifying development, there are conclusions that may be drawn based on the early part of the Thomas hearings. Thomas, too, was willing to assure anxious Democrats that he in some general way recognized the constitutional principles they sought to preserve. "My view is that there is a right to privacy in the Fourteenth Amendment," he told Senator Biden on the first day of his hearings. ${ }^{80}$

As with Souter, Biden tried to press on, this time even more specifically to ask whether the right to privacy protects "the right of a woman to decide for herself in certain instances whether or not to terminate a pregnancy." 81 Thomas declined to answer this more specific question. Other Democrats became equally anxious about being limited to very general philosophical questions, as well as the equally general nature of the responses. This frustration produced one of the more memorable attempts to pin down and engage Thomas's constitutional views, when Democratic Senator Patrick Leahy asked Thomas if he had ever

77. 136 CONG. REC. S14,374 (daily ed. Oct. 2, 1990).

78. For a summary of highlights of the first round of hearings, see SIMON, supra note 57, at 81-99; see also Hearings on the Nomination of Clarence Thomas, supra note 19, pts. I-III.

79. The Senate Judiciary Committee concluded the first chapter on September 27, 1991, with a deadlocked vote of 7-7 and decided to send the Thomas nomination to the full Senate without recommendation. However, with a Senate vote scheduled for October 8th, the news media revealed on October 6th that the Senate had received allegations of sexual harassment against Thomas. The allegations, made by Professor Anita Hill of the University of Oklahoma Law School, were that Thomas had sexually harassed her in 1981 and 1982 while she worked for him, first at the Department of Education and later when Thomas was chairman of the Equal Employment Opportunity Commission. The alleged harassment involved repeated requests for dates, questions and observations about intimate sexual experiences and anatomical characteristics, and descriptive references to pornographic films. The Senate vote was postponed for one week, and the Judiciary Committee resumed hearings on October 11th for three days. Hill aired her allegations, and Thomas denied every aspect of the charges, leaving senators to judge for themselves which of the witnesses they believed. For a full discussion of the Thomas nomination and of the Hill-Thomas controversy, see TIMOTHY M. PHELPS \& HELEN Winternitz, Capitol Games: Clarence Thomas, ANITA Hill, and the Story of a Supreme COURT NOMINATION (1992).

80. Hearings on the Nomination of Clarence Thomas, supra note 19, at 127.

81. Id. 
discussed Roe $v$. Wade with anyone when it came out while he was in law school at Yale or soon thereafter. Thomas replied, "Senator, I cannot remember personally engaging in those discussions." 82

The frustration with Thomas, both individually and as a representative of almost certain constitutional change on the high court, was apparent in the sharp contrast between the Zeitgeist of his confirmation hearings and those of Kennedy and Souter. Although Thomas, like Souter, had a Senate mentor in the person of Senator John Danforth, a Missouri Republican, Thomas remained a controversial figure who may have been facing as many as one-third negative votes in the Senate even before Professor Hill's charges. ${ }^{83}$ The opposition was due in part to Thomas's record of outspoken, controversial positions on important, volatile issues that made the dynamic of his confirmation more closely resemble Bork's than Souter's or Kennedy's. A crucial factor, at the heart of the Senate's new role of influencing constitutional interpretation, was that many senators simply did not believe that they had had any impact on Thomas. Unlike Souter and Kennedy, Thomas's representations and assurances did not put committee members at ease. Senator Howard Metzenbaum, an Ohio Democrat, made his doubts clear to Thomas during the September hearings, accusing him of the same sort of "confirmation conversions" that had been so damaging to Bork:

I will be frank; your complete repudiation of your past record makes our job very difficult ... . For example, yesterday, in response to a question from Sen. Biden, you said that you support a right to privacy. Frankly, I was surprised to hear you say that. I have not been able to find anything in your many speeches or articles to suggest that you support a right to privacy. ${ }^{84}$

There was one important issue in the first set of Thomas hearings, part of the Zeitgeist, that more appropriately fit with the old model: whether Thomas had enough legal experience to be qualified for the job. Critics charged that his experience was largely regulatory, administrative, and political, and that he had never practiced law or spent any time in the courtroom.

Once the charges of sexual harassment were aired in a second set of hearings held a month after the first, however, it was difficult to follow the influence of constitutional interpretation on the Thomas nomination process. The focus became much more personal, and although the charges and rebuttals received sensational attention, this part of the process was much more akin to the traditional Senate effort to assess the nominee's character and fitness. $1991 .^{85}$

Thomas was confirmed by the Senate, by a vote of $52-48$, on October 15 ,

82. Id. at 222 .

83. Joan Biskupic, Thomas Picks Up Support As Senate Nears Vote, CONG. Q. WKLY. REP., Oct. 5,1991 , at 2867 (stating that Sen. Danforth expected Thomas's vote total to be in the 60s).

84. Hearings on the Nomination of Clarence Thomas, supra note 19, at 178.

85. 137 CONG. REC. S14,704-05 (daily ed. Oct. 15, 1991). 


\section{Ruth Bader Ginsburg}

Nominated in June 1993 by President Bill Clinton to replace retiring Justice Byron White, Judge Ruth Bader Ginsburg of the U.S. Court of Appeals for the District of Columbia Circuit was the first nominee of a Democratic president since the nomination of Fortas to be Chief Justice was withdrawn in 1968. The hearings for Ginsburg gave Republican senators their first post-Bork opportunity to step out of the role of loyal supporters of Republican presidents and to ask substantive constitutional questions of a nominee of a Democratic president. Democrats also continued their practice of probing nominees for their constitutional values.

The new political alignment of Democrats controlling both the White House and the Senate changed the dynamic of the hearings markedly: Ginsburg's confirmation was virtually assured as the hearings began. ${ }^{86}$ Yet both Democratic and Republican senators had concerns about Judge Ginsburg's approach to the Constitution, and they used the hearings to voice them and to seek assurances from the nominee. The opening statements of some senators made it clear that this was the direction the hearings would take. Senator Arlen Specter, a Pennsylvania Republican, said he was concerned about the nominee's understanding of "judicial activism." ${ }^{87}$ Senator Orrin Hatch, also a Republican, explained that the issues examined in Ginsburg's hearing would be of the postBork variety, not of the traditional model:

Judge Ginsburg's ability, character, intellect, and temperament to serve on the Supreme Court are not, in my mind, in question ... . A Supreme Court justice, in my view however, must meet an additional qualification. He or she must understand the role of the judiciary, including the Supreme Court, in our system of government. Under our system, a Supreme Court justice should interpret the law, and not legislate his or her own policy preferences from the bench. ${ }^{88}$

Some Democrats also outlined areas of concern with the nominee's constitutional view in their opening statements. Senator Howard Metzenbaum of Ohio said:

As an appeals court judge, Judge Ginsburg is well known for her preference for measured or incremental movement in the law. She speaks of permitting constitutional doctrine, especially in controversial areas, to emerge from a dialogue between the courts, other branches of government and the people .... When Judge Ginsburg speaks of a dialogue, she apparently envisions a concept of gradualism in applying the constitution's provisions. That causes me concern, because any delay in enunciating or protecting constitutional rights is justice denied. ${ }^{89}$

86. Senator Paul Simon, an Illinois Democrat, said in his opening statement that she would likely be confirmed unanimously. Neil A. Lewis, Ginsburg Promises Judicial Restraint If She Joins Court, N.Y. TiMES, July 21, 1993, at A1, C27.

87. Excerpts From Senate Hearings on the Ginsburg Nomination, N.Y. TIMES, July 21, 1993, at C26.

88. Id.

89. Id. 
Most Democrats played a role that was a variation on recent hearings of the past. Questions about the right to privacy and free expression when addressed to Republican nominees had been a search for a floor; the senators sought assurances that the nominee recognized a minimum threshold level of constitutional protection for these rights. In the Ginsburg hearing, however, Democrats were not simply seeking to establish a floor, but also seeking to determine how high above the minimum threshold that floor would be.

For example, there was little question for Democrats about Judge Ginsburg's commitment to free speech. A question from Democratic Senator Patrick Leahy was intended, instead, to see how Judge Ginsburg viewed cutting-edge areas of free speech law. "What about in the area of entertainment?" Leahy asked. ${ }^{90}$ "Well, now we're getting into more slippery territory. It depends what kind of entertainment, I suppose," Judge Ginsburg said, in partial reply. ${ }^{91}$

Massachusetts Senator Edward M. Kennedy expressed his concern that the Supreme Court had "cut back on the legal protections against job discrimination." 92 He then sought, and received, assurances from Judge Ginsburg that she believes Congress intended federal civil rights laws to be read broadly. "The Civil Rights Act states grand principles representing the highest aspirations of our nation to be a nation that is open and free, where all people will have opportunity," Judge Ginsburg said.93 Kennedy did not stop there, however, asking whether the nominee still believed, as she had said in a 1979 speech, that discrimination based on sexual orientation should also be deplored. ${ }^{94}$ "I think rank discrimination against anyone is against the tradition of the United States and is to be deplored," Judge Ginsburg responded..$^{95}$

Perhaps the most significant questioning of Judge Ginsburg was over the death penalty. It was on that issue that Democrats and Republicans most clearly sought simultaneous assurances from opposite ends of the constitutional spectrum. Senator Metzenbaum sought some sign that Judge Ginsburg would be a moderating influence on the Supreme Court's death penalty decisions, asking her for her opinion on a recent decision, Herrera v. Collins. ${ }^{96}$ Republican senators, conversely, looked for assurances that Judge Ginsburg was not an abolitionist who would refuse to apply the death penalty. ${ }^{97}$

Judge Ginsburg maintained her firm refusal to discuss specific issues on which she had taken no position that might come before the Supreme Court. ${ }^{98}$ However, apparently sensing the importance of the death penalty to her

90. Excerpts From Senate Hearings on Ginsburg Nomination, N.Y. TIMES, July 23, 1993, at A16.

91. Id.

92. Id.

93. Id.

94. Id.

95. Id.

96. $113 \mathrm{~S}$. Ct. 853 (1993) (holding that the Constitution does not guarantee a new hearing, on a habeas corpus petition, to a convicted individual who says he has new evidence of his innocence, even when the convicted person has been sentenced to death).

97. Excerpts From Senate Hearings on the Ginsburg Nomination, supra note 90, at A16.

98. Id. 
hearings, she offered a number of assurances to Republican and moderate Democratic senators that she understood the Supreme Court's impatience with long delays and repeat appeals in death penalty cases. To Hatch's question about the death penalty, she replied, "I can tell you that I am well aware of the precedent, and I have already expressed my views on the value of precedent." On another occasion, she remarked, "I will be scrupulous in applying the law on the basis of legislation and precedent."100

If the death penalty was a focal point of Judge Ginsburg's hearings, the issue of abortion was less so, in part because of her well-established record as a champion of women's rights in the 1970s. Because of her record on the issue, Ginsburg was free to be direct with the Judiciary Committee. Responding to a question from Republican Senator Hank Brown, Ginsburg said, "This is something central to a woman's life, to her dignity. It's a decision that she must make for herself. And when government controls that decision for her, she's being treated as less than a fully adult human responsible for her own choices."101

There was another reason she could be so direct on abortion without strong negative consequences among senators who oppose abortion. Judge Ginsburg went out of her way to reassure senators that she was not a "judicial activist," even invoking the words of Justice Oliver Wendell Holmes when she said, "...Holmes counseled one of the most sacred duties of a judge is not to read her convictions into the Constitution. I have tried and will continue to try to follow the model Justice Holmes set in holding that duty sacred."102 Her assurances about the proper role of a judge helped to alleviate many of the concerns that Republicans felt about her stance on abortion. ${ }^{103}$ $1993 .{ }^{104}$

By a vote of 96-3, Ginsburg was confirmed by the Senate on August 3,

IV

\section{EARLY EVALUATION}

Since this concept of the confirmation process as an influence on constitutional interpretation is a relatively novel one, it is, perhaps, too early to assess its efficacy. Nevertheless, some observations can be made and some questions for future consideration can be raised.

The effort to influence constitutional interpretation by telling nominees what senators consider mainstream constitutional jurisprudence is tricky, because it

99. Id.

100. Excerpts From Senate Hearing on the Ginsburg Nomination, N.Y. TIMES, July 22, 1993, at A20.

101. Id.

102. Excerpts From Senate Hearing on Ginsburg Nomination to Supreme Court, N.Y. TIMES, July 21,1993 , at C27.

103. For a discussion of the significance of her view of the judicial role, see Linda Greenhouse, $A$ Sense of Judicial Limits, N.Y. TIMES, July 22, 1993, at A1.

104. 139 CONG. REC. S10,163 (daily ed. Aug. 3, 1993). 
comes close to the delicate line between what nominees for the Supreme Court may fairly discuss and what would render them unable to maintain an appearance of impartiality in a future case. It is apparent from the Kennedy, Souter, Thomas, and Ginsburg hearings that this line is best avoided by posing broad questions of constitutional generality rather than focusing too specifically on particular cases.

Thus, questions about the existence of and foundation for a right to privacy would appear to be appropriate and somewhat effective, but direct questions about abortion are of little value even though they may be at the heart of senators' concerns. ${ }^{105}$ General questions about whether the right to privacy encompasses marital sexual privacy were more likely to elicit informative responses than were questions framed specifically around the holding of Griswold v. Connecticut. ${ }^{106}$ Questions about whether the Ninth Amendment might be a general repository for the recognition and protection of unenumerated rights are more effective than a dialogue over whether it is the specific locus of the right to privacy. Finally, a discussion of stare decisis and how and when to apply it elicits a more valuable response than a discussion of the validity of specific precedents like Roe $v$. Wade. ${ }^{107}$

This assessment addresses only one facet of efficacy: what types of questions are likely to elicit productive and responsive answers about constitutional interpretation. The more difficult task is measuring whether this approach to Senate confirmations makes any difference in outcomes. It is difficult to determine whether the views that a nominee held prior to appointment to the Supreme Court have been influenced even in part by the Senate confirmation process. It also depends very much on which nominee one is analyzing.

With Souter and Kennedy, it is hard to escape the conclusion that the hearings had some impact, without resolving the question of whether the effect was to change or simply to reinforce their views. The decisions in Lee $v$. Weisman $^{108}$ and Planned Parenthood v. Casey ${ }^{109}$ would appear to stand as monuments to the success of Judiciary Committee Democrats. In Weisman, the Supreme Court ruled that the recital of a nondenominational prayer at a junior high school graduation violated the establishment clause. ${ }^{110}$ Writing for the majority, Kennedy rejected the suggestion of the Bush Justice Department and of school authorities that the Court reconsider the leading Establishment Clause decision of Lemon v. Kurtzman, ${ }^{111}$ which Kennedy had criticized on other

105. Justice Ginsburg's hearing was an exception to this proposition, since she spoke so forthrightly and specifically about abortion. See supra text accompanying notes 101-04.

106. 381 U.S. 479 (1965).

107. 410 U.S. $113(1973)$.

108. 112 S. Ct. 2649 (1992).

109. 112 S. Ct. 2791 (1992).

110. U.S. CONST. amend. I ("Congress shall make no law respecting an establishment of religion . ...).

111. 403 U.S. 602 (1971). Lemon establishes a three-part test to assess whether government action violates the establishment clause. To pass muster, a measure must have a secular purpose, must neither advance nor inhibit religion, and must avoid excessive entanglement in religion. Id. at 612-13. The test 
occasions. Sounding much like a Judiciary Committee dialogue on the subject, Kennedy said that well-established precedents were sufficient to ascertain the unconstitutionality of the practice and that there was no reason to revisit those precedents. ${ }^{112}$ Souter joined Kennedy's majority opinion and wrote a concurrence of his own. ${ }^{113}$

In Casey, a case which many observers had believed would be the vehicle for reconsidering and possibly overruling Roe, Souter and Kennedy were joined by O'Connor in a dramatic joint opinion generally reaffirming constitutional protection for the right of women to choose to have an abortion. The essential factor for the three was "the explication of individual liberty we have given combined with the force of stare decisis."114 The lengthy discussion of liberty and stare decisis reads very much like a confirmation hearing dialogue.

Justice Thomas's opinions, on the other hand, evince no effect of the confirmation process. In both Weisman and Casey, he was among the dissenters in the 5-4 decisions. By joining both dissents, he made it clear that his commitment to stare decisis is not the same as Kennedy's and Souter's. Indeed, he has given no indication thus far of having heard the message of Senate Democrats. Thomas has also failed to demonstrate his own stated commitment to privacy as a protected constitutional interest. ${ }^{115}$ His actions are consistent with the skepticism of those senators who doubted the sincerity of his answers during his confirmation hearings.

Conclusions about the impact of the senators' questioning on Justice Ginsburg is, of course, premature. As with the other nominees, it may be difficult to tell in the future whether positions she takes on issues that she has not previously addressed reflect any influence of the hearings.

\section{$\mathrm{V}$ \\ CONCLUSION}

While this analysis suggests a mixed track record for the confirmation hearing as a tool for influencing constitutional decisionmaking, such a conclusion misses the constitutional significance of what has occurred. Senators have succeeded in establishing a new purpose to the confirmation hearing for Supreme Court nominees. It is one in which senators can identify points of constitutional concern and pursue those concerns with nominees, with the hope that, once confirmed, the new Justices will remember the importance of the core values urged on them by the senators or at least feel bound by the assurances they gave during their hearings.

has generally been credited with erecting a relatively high wall of separation between church and state.

112. Weisman, 112 S. Ct. at 2655.

113. Id. at 2667.

114. Casey, 112 S. Ct. at 2808.

115. In his most significant privacy case thus far, Thomas joined both Chief Justice Rehnquist's concurrence/dissent in Casey, id. at 2855, which urged that Roe be overruled and Justice Scalia's concurrence/dissent, id. at 2873 , which also urged overruling Roe. 
Senate Democrats have now established this model and adhered to it with relative uniformity during the last several nominations. This development in itself would be reason enough to suggest that similar discourse is likely to be required of future Supreme Court nominees. Democratic senators may have met with some measurable success in only two of the last four nominations-Thomas having engaged in a constitutional dialogue that was one-sided, and Ginsburg having been favorably inclined toward many views of Democratic senators before the hearings. But two of four is still a strong record and one that reinforces the value of the post-Bork era model for confirmation hearings.

There are some points on which Democrats and Republicans may agree when pressing paramount concerns on future Supreme Court Justices. The most likely candidate in this category of joint ventures is constitutional concern about statutory interpretation. Specifically, senators on both sides of the aisle have expressed concern in recent confirmation hearings with statutory interpretation as a matter of constitutional separation of powers, focusing on the views of Justice Scalia and some other Justices that legislative history and congressional debate is to be ignored because it is not an honest reflection of legislative intent. This is an issue that is of much concern to Democrats and Republicans alike, and one that would be well-served by the modern confirmation hearing model if the two parties united to press the point.

The Democratic party currently controls both the White House and the Senate, and the apparent need for the post-Bork era hearing model may diminish for senate Democrats. However, it has never been and is not now the sole province of liberal Democrats to inquire into the constitutional thinking of Supreme Court nominees. There are issues that Republicans found it desirable to press on Justice Ginsburg and may continue to raise with the Supreme Court nominees of President Clinton if there are more vacancies in the next few years. For example, Republicans on the Judiciary Committee may seek to satisfy themselves that a Clinton nominee accepts that the Eighth Amendment ${ }^{116}$ does not prohibit the death penalty, ${ }^{117}$ or similarly that the Eighth Amendment does not bar prosecutors in capital cases from presenting victim impact evidence, as the Court held in Payne v. Tennessee. ${ }^{118}$ Republicans may seek to impress a nominee with their opinion that the Court correctly ruled that minority set-aside programs for state and local government contracts violate the Equal Protection Clause $^{119}$ unless they are justified by high standards of necessity and tailored in the narrowest of terms. ${ }^{120}$ Finally, another likely candidate for constitutional

116. U.S. CONST. amend. VIII ("Excessive bail shall not be required, nor excessive fines imposed, nor cruel and unusual punishments inflicted.").

117. See Gregg v. Georgia, 428 U.S. 153 (1976).

118. 111 S. Ct. 2597 (1991) (overruling Booth v. Maryland, 482 U.S. 496 (1987), and South Carolina v. Gathers, 490 U.S. 805 (1989)).

119. U.S. CONST. amend. XIV (stating in relevant part that "[n]o state shall . . deny to any person within its jurisdiction the equal protection of the laws").

120. Richmond v. J.A. Croson Co., 488 U.S. 469 (1989). 
dialogue is the Court's recent narrowing of the availability and scope of federal habeas corpus ${ }^{121}$ remedies, especially in death penalty cases. ${ }^{122}$

These observations suggest a consistency that may be premature. However, the profound nature of this change in confirmation hearings makes it likely that the new model will continue to be employed in the foreseeable future. Democrats and Republicans alike have come to believe that there is too much at stake in the Supreme Court to leave the selection of Justices to the traditional test of good character and adequate experience. As Democratic Senator Paul Simon, a Judiciary Committee member, has observed, "we can view the decisionmaking for Supreme Court nominations not as a political game to be exercised by competing political parties or different branches of government, but what in fact it is: an awe-inspiring opportunity to defend basic freedoms and to provide justice to future generations." 123

121. Habeas corpus is the Latin term for a writ that starts a civil proceeding in which an incarcerated person challenges the legality of his or her confinement. BLACK's LAW DICTIONARY 709 (6th ed. 1990).

122. See, e.g., Coleman v. Thompson, 111 S. Ct. 2546 (1991) (holding that failure to comply with procedural rules for filing a habeas corpus petition in state court that includes claims based on federal law bars subsequent federal court review of those claims in a habeas corpus petition, unless the petitioner can show cause for the procedural default), and Teague v. Lane, 489 U.S. 288 (1989) (holding that newly announced constitutional rules of criminal procedure do not apply retroactively to cases on collateral review, such as habeas corpus).

123. SIMON, supra note 57 , at 27. 